\title{
Parking Space Occupancy at Rail Stations in Klang Valley
}

\author{
Phooi Wai Ho ${ }^{1, *}$ S. M. Sabri Ismail $^{2}$, and Premkumar Rajagopal ${ }^{3}$ \\ ${ }^{1}$ School of Science and Engineering, Transportation and Logistics Department, Malaysia University \\ of Science and Technology, Petaling Jaya, Malaysia \\ ${ }^{2}$ Research and Development, PRAISE, Prasarana Malaysia Berhad, Kuala Lumpur, Malaysia \\ ${ }^{3}$ School of Science and Engineering, Transportation and Logistics Department, Malaysia University \\ of Science and Technology, Petaling Jaya, Malaysia
}

\begin{abstract}
The development of Klang Valley Integrated Rapid Transit system in Klang Valley, Malaysia has been quickly gaining momentum during the recent years. There will be two new MRT lines (MRT Line 1 and MRT Line 2) and one new LRT line (LRT Line 3) extended from the current integrated rail transit system by year 2020 with more than 90 new rail stations. With the substantial addition of potential rail passengers, there are doubts whether the existing Park and Ride facilities in Klang Valley are able to accommodate the future parking space demand at rail stations. This research studies the parking occupancy at various Park and Ride facilities in Klang Valley namely Taman Jaya, Asia Jaya, Taman Paramount, Taman Bahagia and Kelana Jaya by applying the non-conventional method utilizing Google Earth imageries. Results showed that the parking occupancy rate at these LRT stations were $100 \%$ or more before the commencement of LRT extension (Kelana Jaya and Ampang Lines) in 2016 and in the range of $36 \%$ to $100 \%$ after the commencement of LRT extension due to the additionally built car parks and changes in parking pattern with dispersed passenger traffic.
\end{abstract}

\section{Introduction}

The Klang Valley Integrated Rail Transit system in Klang Valley, Malaysia comprises of four existing rail transit line namely, KTM Commuter, Kuala Lumpur (KL) Monorail, KLIA Express Line and Light Rail Transit (LRT) [1]. During the initial stage of this research, the construction of the LRT Extension was underway with the extension of Kelana Jaya and Ampang lines, with additional 13 stations each [1]. At the same time, the construction of the new MRT Line 1 is also underway with 31 rail stations. Thereafter, the construction of MRT Line 2 and LRT Line 3 will commence with 35 and 25 rail stations respectively [2], [3]. The MRT Line 1 is scheduled for completion in July 2017 while both the MRT Line 2 and LRT Line 3 are scheduled for completion in year 2020 [2], [3].

These huge expansion of MRT and LRT projects will be extended into outlying suburbs and upgraded to a full-fledged integrated rail transit system. This is part of the blueprint of

* Corresponding author: phooiwai@gmail.com 
the Malaysia Land Public Transport Commission (SPAD), which has set out an integrated 20 year plan to transform land public transportation in the region to respond to local needs and aspirations [4], which will see a total of 91 new rail stations by year 2020 [2], [3]. This is indeed in line with Malaysia's aim to increase public transportation modal share from $18.1 \%$ in 2014 to $40 \%$ by year 2030 [5] and to achieve transportation sustainability and a high income and developed nation by year 2020, with a world class rail transit system [6].

\section{Historical data of parking occupancy at Park and Ride facilities}

Researches have been conducted to study the parking occupancy at Park and Ride (P\&R) facilities namely at Putrajaya Sentral, Shah Alam, Seremban, Kelana Jaya, Gombak and Rawang rail stations. The parking occupancy rates range from $90 \%$ to $100 \%$ as shown in Table 1 [7]-[12]. Parking occupancy rates above $85 \%$ showed parking problems at car parks where the efficiency flow of cars coming and going will be affected [13]. The high parking occupancy rates also showed that there were parking space constraint at these rail stations. The most recent parking occupancy rates are probably more than before due to the increase of population, car registrations and rail ridership throughout the years [14-17].

Table 1. Parking occupancy at Park and Ride facilities [7-12].

\begin{tabular}{|l|c|}
\hline Park and Ride Facility & Parking Occupancy Rate \\
\hline ERL Putrajaya (Surface parking) & $95 \%$ \\
\hline ERL Putrajaya (Multi-storey parking) & $90 \%$ \\
\hline KTM Shah Alam & $95 \%$ \\
\hline KTM Seremban & $95 \%$ \\
\hline LRT2 Kelana Jaya & $92 \%$ \\
\hline LRT2 Gombak & $100 \%$ \\
\hline KTM Rawang & $100 \%$ \\
\hline
\end{tabular}

With the rapid expansion of the new rail transit projects, there are doubts whether the future parking space at $P \& R$ facilities will be able to accommodate the sudden rise of rail passengers. In the case if there is lack of parking space at $P \& R$ facilities after the implementation of the new rail lines, this may cause massive traffic congestion [18], [19], thus air pollution [20], [21] and the limitation of rail transit system ridership [22]-[25] for the Klang Valley integrated rail transit system. Therefore, it is crucial to examine the parking occupancy at $\mathrm{P} \& \mathrm{R}$ facilities to be able to plan for the future parking demand.

\section{Parking space occupancy at Park and Ride facilities}

This research studied the parking occupancy at various P\&R facilities in Klang Valley along the Kelana Jaya LRT Line namely Taman Jaya, Asia Jaya, Taman Paramount, Taman Bahagia and Kelana Jaya by applying the non-conventional method utilizing Google Earth imageries. The parking data for these facilities were taken from Google Earth images on Monday, $2^{\text {nd }}$ November 2015 between $8.35 \mathrm{am}$ to $5.47 \mathrm{pm}$ on a normal working weekday. For images that were blocked by trees, buildings or other structures, an on-site survey and observation were conducted on Tuesday, $2^{\text {nd }}$ February 2016 between 9.00am to 11.00am. 


\subsection{Taman Jaya Park and Ride facilities}

The Taman Jaya LRT station, KJ20, is situated along Persiaran Barat, Section 52, Petaling Jaya and is set around the neighbourhood of Section 9, 10 and 11, Petaling Jaya. The P\&R facilities are located next to the LRT station (Reserved Car Park) and along Lorong Sultan not far away from the LRT station (Car Park 1).

The Taman Jaya Reserved Car Park is dedicated for the special needs. From Google Earth image, the car park was partially blocked by trees. Based on a site survey, there were 4 car parking bays and all of them were occupied. The parking occupancy rate was $100 \%$ with no parking charges. Other observed parking areas at the car park were for taxis, buses and cars pick-up and drop-off. There were 11 car parking bays for cars pick-up and dropoff, 3 of which were occupied. However, these car parking bays were not for P\&R purpose.

The Taman Jaya Car Park 1, is a common car park managed by Majlis Bandaraya Petaling Jaya (MBPJ), the local municipal council. From Google Earth image, there were 59 parking bays and all of them were occupied. The parking occupancy rate was $100 \%$. The parking fee for Taman Jaya Car Park 1 was RM0.60 per hour, a standard for all MBPJ bays in town. These car parking bays do not only cater for LRT passengers. In fact, these parking bays were shared for all premises nearby the LRT station such as A\&W restaurant, Kelab PJ Sports and Recreation Club, Shah's Village Hotel, PJ Palms Sports Centre and a local food court.

Besides the MBPJ managed car park, there were also other private car parking operators operating along the road with their own private parking space. For example, the valet parking operated by PJ Palms Sports Centre charges RM3.00 per hour, RM5.00 per 3 hours or RM15.00 per 24 hours. There were also other commercial car parks opposite the LRT station such as Yayasan Selangor (Open Site $1 \&$ 2), Yayasan Selangor (Petaling Jaya), Amcorp Trade Centre and PJX PJ Exchange. The Yayasan Selangor (Open Site 1 \& 2) charges RM5.00 for 2 hours and RM4.00 for subsequent hours. Yayasan Selangor (Petaling Jaya) charges RM4.00 for the $1^{\text {st }}$ hour and RM3.00 for subsequent hours. Amcorp Trade Centre charges RM3.00 for the first 3 hours and RM2.00 for subsequent hours. Lastly, PJX PJ Exchange charges RM3.00 for the $1^{\text {st }}$ hour and RM2.00 for subsequent hours.

The parking occupancy rate of $100 \%$ for the Taman Jaya Reserved Car Park is expected because there were only 4 parking bays. Moreover, there were no parking charges. Likewise, the parking occupancy rate of $100 \%$ for the Taman Jaya Car Park 1 is also expected because not only does this car park caters for LRT passengers but also for visitors at other nearby premises. Furthermore, the other nearby commercial car parks were charging much more than the MBPJ bays. The cheapest commercial car park is Amcorp Trade Centre with parking fee RM3.00 for the first 3 hours and RM2.00 for subsequent hours, while other commercial car parks charges up to RM4.00 for the first hour and RM3.00 for subsequent hours, which makes it reluctant for LRT passengers to park at these commercial car parks. The parking situation at the Taman Jaya LRT station is similar to the scenario at the Gombak LRT station in 2015 where the parking occupancy rate was $100 \%$ [10].

Table 2. Parking occupancy at Taman Jaya Park and Ride facilities.

\begin{tabular}{|l|c|c|c|}
\hline $\begin{array}{l}\text { Taman Jaya } \\
\text { Park and Ride }\end{array}$ & $\begin{array}{c}\text { No. of Car Parking } \\
\text { Bays }\end{array}$ & $\begin{array}{c}\text { No. of Occupied Car } \\
\text { Parking Bays }\end{array}$ & $\begin{array}{c}\text { Parking } \\
\text { Occupancy Rate }\end{array}$ \\
\hline Reserved Car Park & 4 & 4 & $100 \%$ \\
\hline Car Park 1 & 59 & 59 & $100 \%$ \\
\hline Total Average & 63 & 63 & $100 \%$ \\
\hline
\end{tabular}




\subsection{Asia Jaya Park and Ride facilities}

The Asia Jaya LRT station, KJ21, is situated Off Jalan Utara and Jalan 51A/223. It is set around the industrial and commercial districts of Section 51A \& Section 52, and is near the residential neighbourhood of Section 8 and Section 14, Petaling Jaya. The P\&R facilities are located next (Reserved Car Park and Car Park 1) and behind (Car Park 2) the LRT station.

The Asia Jaya Reserved Car Park is dedicated for staff of Rapid KL, subsidiary of Prasarana. From Google Earth image, the car park was mostly blocked by the LRT station. Based on a site survey, there were 49 cars at the car park squeezed into 44 of the car parking bays. Cars were seen double parking, parked next to and in front of one another. The parking occupancy rate was $111 \%$ with no parking charges.

From Google Earth image, the Asia Jaya Car Park 1 has 9 car parking bays and all of them were occupied with 1 car was seen parking illegally at the end of the parking bays. The parking occupancy rate was $111 \%$ with no parking charges.

The Asia Jaya Car Park 2 was built in 2014 to curb the parking constraint problem at the LRT station. The parking fee is RM3.00 per entry. Officially, there was a total of 607 parking bays catered for the needs. However, Google Earth image indicated that the total cars parked was 632 numbers, 25 more cars than the allocated bays. Cars were also seen to be parking at every nook and corners possible. However, 3 empty parking bays were found. Since 4 cars were seen driving at the car park, the 3 empty parking bays will most probably also be parked. Due to the aggressive parking pattern at the car park and the number of cars parked were more than the actual allocated parking bays, the parking occupancy rate was considered $104 \%$ even though there was 3 parking bays spotted empty. The parking occupancy rate was $104 \%$.

Besides the car park managed by Prasarana and MBPJ, there were also other private car parks around the vicinity of the Asia Jaya LRT station with the nearest private car park located just 100 meters away from the entrance of the LRT station. The car park was always full during normal working days with cars starting to park from as early as 6.00am until 9.00am to reach its full parking occupancy of about 250 car parking bays. This car park also catered for office workers nearby and it charges RM6.00 per entry. Other commercial car parks within 300 meters from the LRT station, such as Menara Axis, Crystal Plaza and Menara LYL charges RM3.00 for the 1st hour and RM2.00 for subsequent hours on Mondays to Fridays during office hours.

The parking occupancy rate of $111 \%$ at the Asia Jaya Reserved Car Park is expected because not only does this car park caters for the personnel permanently based at this LRT station. It also caters for other visiting Prasarana's personnel from other locations. Likewise, the parking occupancy rate of $111 \%$ for the Asia Jaya Car Park 1 is also expected because there were only 9 bays. Most of all, there were no parking charges for these parking bays and they were also the nearest to the LRT station. The same goes to the Asia Jaya Car Park 2 where the parking occupancy rate of 104\% is expected because based on the Google Earth image in December 2014, it has already been long shown to have full parking occupancy. The high parking fee charges at the nearby commercial car parks may drive office workers to park at the Asia Jaya Car Park 2 instead. The cheapest commercial car park charges RM6.00 per entry but it was always full. Therefore, the next alternative is RM3.00 for the 1st hour and RM2.00 for the subsequent hours. This makes the parking fee at the Car Park 2 looks attractive with only RM3.00 per entry.

The situation at the Reserved Car Park and Car Park 1 were similar to the scenario at the Putrajaya P\&R facility where double parking and illegal parking were observed [26]. Also, the situation at the Car Park 2 were similar to the scenario at the Rawang P\&R facility with double parking and $100 \%$ parking occupancy rate [12]. 
Table 3. Parking occupancy at Asia Jaya Park and Ride facilities.

\begin{tabular}{|l|c|c|c|}
\hline $\begin{array}{l}\text { Asia Jaya } \\
\text { Park and Ride }\end{array}$ & $\begin{array}{c}\text { No. of Car Parking } \\
\text { Bays }\end{array}$ & $\begin{array}{c}\text { No. of Occupied Car } \\
\text { Parking Bays }\end{array}$ & $\begin{array}{c}\text { Parking } \\
\text { Occupancy Rate }\end{array}$ \\
\hline Reserved Car Park & 44 & 49 & $111 \%$ \\
\hline Car Park 1 & 9 & 10 & $111 \%$ \\
\hline Car Park 2 & 607 & 632 & $104 \%$ \\
\hline Total Average & 660 & 691 & $105 \%$ \\
\hline
\end{tabular}

\subsection{Taman Paramount Park and Ride facilities}

The Taman Paramount LRT station, KJ22, is situated at the edge of Jalan 21/1. It is set near the neighbourhood of Section 14, 20, 21 and 22 as well as Kampung Tunku in Section SS1, Petaling Jaya. The P\&R facility is located behind the LRT station (Car Park 1). The Taman Paramount Car Park 1 was able to accommodate up to 87 cars and all of them were fully occupied from as early as 7.00am. There were also 3 cars double parking in the parking area. The parking occupancy rate was $100 \%$ with parking fee of RM3.00 per entry.

The parking occupancy rate of $100 \%$ at the Taman Paramount Car Park 1 is expected because this scenario can clearly be seen on Google Earth image since 2013. The situation of parking space constraint at the Taman Paramount LRT station is similar to the scenario at the same station back in 2013, where double parking was observed [27].

Table 4. Parking occupancy at Taman Paramount Park and Ride facilities.

\begin{tabular}{|l|c|c|c|}
\hline $\begin{array}{l}\text { Taman Paramount } \\
\text { Park and Ride }\end{array}$ & $\begin{array}{c}\text { No. of Car Parking } \\
\text { Bays }\end{array}$ & $\begin{array}{c}\text { No. of Occupied Car } \\
\text { Parking Bays }\end{array}$ & $\begin{array}{c}\text { Parking } \\
\text { Occupancy Rate }\end{array}$ \\
\hline Car Park 1 & 87 & 87 & $100 \%$ \\
\hline
\end{tabular}

\subsection{Taman Bahagia Park and Ride facilities}

The Taman Bahagia LRT station, KJ23, is situated along Jalan SS2/3 near the LDP interchange at Taman Megah and is set near the neighbourhood of SS2, SS3, SS4 and SS23. The P\&R facilities are located directly next to the LRT station (Reserved Car Park) and at the back of the LRT station (Car Park 1).

The Taman Bahagia Reserved Car Park is dedicated for the staff of Prasarana. From Google Earth image, the car park was partially blocked by the LRT track. Based on a site survey, there were 6 cars squeezed into a small area catered for 4 cars. Cars were seen double parking in front of the row of car parks. The parking occupancy rate was $150 \%$ with no parking charges. Meanwhile, the road just outside of the LRT station was also parked with cars. Furthermore, the narrow lane near the residential area behind the LRT station was parked with cars on both sides of the lane. Unfortunately, these were not proper car parking bays. However, due to the lack of parking space, these cars just parked there anyway.

The Taman Bahagia Car Park 1 is an empty space car park managed by MBPJ with no parking fee imposed yet. From Google Earth image, there were a total of 81 cars parked at the parking bays and 79 of the parking bays were occupied. Some cars were seen parking right up to the entrance of the car park. The parking occupancy rate was $98 \%$.

The parking occupancy rate of $150 \%$ at the Taman Bahagia Reserved Car Park is expected because not only does this car park caters for the personnel permanently based at this LRT station. It also caters for other visiting Prasarana's personnel from other locations. Moreover, the double parking, illegal and indiscriminate parking around the LRT station up to the nearby neighbourhood showed that there was need for more parking. Likewise, the parking occupancy rate of $98 \%$ for Car Park 1 is also expected because that was the only 
empty space near the LRT station. Most of all, there were no parking charges at this car park. The situation at the Taman Bahagia Reserved Car Park and Car Park 1 were similar to the scenario at the same LRT station back in 2009 where illegal parking were seen around the LRT station [28].

Table 5. Parking occupancy at Taman Bahagia Park and Ride facilities.

\begin{tabular}{|l|c|c|c|}
\hline $\begin{array}{l}\text { Taman Bahagia } \\
\text { Park and Ride }\end{array}$ & $\begin{array}{c}\text { No. of Car Parking } \\
\text { Bays }\end{array}$ & $\begin{array}{c}\text { No. of Occupied Car } \\
\text { Parking Bays }\end{array}$ & $\begin{array}{c}\text { Parking } \\
\text { Occupancy Rate }\end{array}$ \\
\hline Reserved Car Park & 4 & 6 & $150 \%$ \\
\hline Car Park 1 & 81 & 79 & $98 \%$ \\
\hline Total Average & 85 & 85 & $100 \%$ \\
\hline
\end{tabular}

\subsection{Kelana Jaya Park and Ride facilities}

The Kelana Jaya LRT station, KJ24, is situated along the busy Damansara Puchong Expressway. It is set near the neighbourhood of SS2, Kelana Jaya (SS4 and SS5) and Taman Mayang (SS25). The P\&R facilities are located beside (Reserved Car Park and Car Park 1) and behind (Car Park 2) the LRT station.

The Kelana Jaya Reserved Car Park is dedicated for staff of Prasarana. From Google Earth image, the car park was partially blocked by LRT tracks. Based on a site survey, there were 6 cars at the reserved car park where all of the parking bays were occupied. The parking occupancy rate was $100 \%$ with no parking charges.

From Google Earth image, the Kelana Jaya Car Park 1 was partially blocked by LRT tracks and trees. However, it can be seen that the car park was fully occupied with double parking. Based on a site survey, there were 322 cars squeezed into all 282 parking bays. The parking occupancy rate was $114 \%$ with parking fee of RM4.00 per entry.

The Kelana Jaya Car Park 2 was partially blocked by LRT tracks and a high tension pylon on Google Earth image. However, it can be seen that the car park was fully occupied. Based on a site survey, all 241 parking bays were occupied with 4 cars parked outside of the entrance of the car park. The parking occupancy rate was $102 \%$ with parking fee of RM4.00 per entry.

Besides the car parks managed by Prasarana, there were 2 private car parks operating near the LRT station which charges RM4.00 per entry. The entrance to these 2 car parks was from Jalan SS4C/1. From Google Earth image, Private Car Park 1 was almost fully occupied with little space at the far end of the car park, while Private Car Park 2 was fully occupied.

Table 6. Parking occupancy at Kelana Jaya Park and Ride facilities.

\begin{tabular}{|l|c|c|c|}
\hline $\begin{array}{l}\text { Kelana Jaya } \\
\text { Park and Ride }\end{array}$ & $\begin{array}{c}\text { No. of Car Parking } \\
\text { Bays }\end{array}$ & $\begin{array}{c}\text { No. of Occupied Car } \\
\text { Parking Bays }\end{array}$ & $\begin{array}{c}\text { Parking } \\
\text { Occupancy Rate }\end{array}$ \\
\hline Reserved Car Park & 6 & 6 & $100 \%$ \\
\hline Car Park 1 & 282 & 322 & $114 \%$ \\
\hline Car Park 2 & 241 & 245 & $102 \%$ \\
\hline Total Average & 529 & 573 & $108 \%$ \\
\hline
\end{tabular}

The parking occupancy rate of $100 \%$ at the Kelana Jaya Reserved Car Park is expected because this car park caters for Prasarana's personnel permanently based at this LRT station and from other locations. Likewise, the parking occupancy rate of $114 \%$ and $102 \%$ respectively for the Kelana Jaya Car Park 1 and Kelana Jaya Car Park 2 were also expected because Kelana Jaya LRT station is the terminus station along the Kelana Jaya LRT Line. Based on Google Earth image on 10th May 2013, it has already been long shown to have 
full parking occupancy. The situation at the Reserved Car Park, Car Park 1 and Car Park 2 were similar to the scenario at the same LRT station back in 2009 where illegal parking were seen around the LRT station [28].

\section{Parking space occupancy after the implementation of LRT extension}

By $30^{\text {th }}$ June 2016, all of the new rails stations on Ampang and Kelana Jaya LRT extension have commenced operations [29]. There were also additional car parks built at some of the LRT stations under the scope of works of this research, namely Taman Paramount, Taman Bahagia and Kelana Jaya LRT stations. Therefore, after the commencement of the LRT Extension, there were changes in parking patterns at the P\&R facilities. Thus, additional research was conducted at P\&R facilities at the 5 LRT stations from $29^{\text {th }}$ August 2016 till $8^{\text {th }}$ September 2016 on a normal working weekday between $8.30 \mathrm{am}$ to $11.00 \mathrm{am}$.

The average parking occupancy rate at Taman Jaya, Asia Jaya, Taman Paramount, Taman Bahagia and Kelana Jaya Park and Ride facilities after the commencement of the LRT extension were $100 \%, 83 \%, 49 \%, 36 \%$ and $79 \%$ respectively as shown in Table 7.

Table 7. Parking occupancy at Park and Ride facilities after the commencement of LRT extension.

\begin{tabular}{|l|c|c|c|c|c|}
\hline $\begin{array}{l}\text { Park and Ride } \\
\text { Facility }^{\dagger}\end{array}$ & $\begin{array}{c}\text { Reserved } \\
\text { Car Park }\end{array}$ & $\begin{array}{c}\text { Car Park } \\
\mathbf{1}\end{array}$ & $\begin{array}{c}\text { Car Park } \\
\mathbf{2}\end{array}$ & $\begin{array}{c}\text { Car Park } \\
\mathbf{3}\end{array}$ & $\begin{array}{c}\text { Total } \\
\text { Average }\end{array}$ \\
\hline Taman Jaya & $100 \%(4)$ & $100 \%(59)$ & - & - & $100 \%$ \\
\hline Asia Jaya & $100 \%(44)$ & $100 \%(9)$ & $81 \%(492)$ & - & $83 \%$ \\
\hline Taman Paramount & - & $100 \%(87)$ & $36 \%(123)$ & - & $49 \%$ \\
\hline Taman Bahagia & $100 \%(6)$ & $100 \%(104)$ & $0 \%(0)$ & Pending & $36 \%$ \\
\hline Kelana Jaya & $100 \%(6)$ & $114 \%(321)$ & $38 \%(91)$ & Pending & $79 \%$ \\
\hline
\end{tabular}

\section{Conclusion}

The average parking occupancy rate at Taman Jaya, Asia Jaya, Taman Paramount, Taman Bahagia and Kelana Jaya P\&R facilities were 100\%, 105\%, 100\%, 100\% and 108\% respectively, which showed that there were parking space constraint at the LRT stations, where parking occupancy rates above $85 \%$ showed parking problems at car parks where the efficiency flow of cars coming and going will be affected [13].

After the commencement of LRT extension, the parking space constraint at the Taman Jaya LRT station remains, while Asia Jaya, Taman Paramount, Taman Bahagia and Kelana Jaya LRT stations do not show any parking constraint anymore. For Taman Bahagia and Taman Paramount, the occupancy drop were due to new car park built at the stations. However, the increase of the total number of occupied parking bays were obvious, from 85 to 110 bays at Taman Bahagia and from 87 to 210 bays at Taman Paramount. For Asia Jaya and Kelana Jaya, the occupancy drop were possibly due to more car parks built at the new LRT extension rail stations such as Ara Damansara, Glenmarie, USJ21, Alam Megah, Subang Alam and Putra Heights. Therefore, parking pattern has changed with dispersed passenger traffic. Even though the occupancy rates were $36 \%$ and $79 \%$ respectively at Taman Bahagia and Kelana Jaya LRT station, the authorities are still building car parks to cater for the future parking demand after the implementation of the upcoming new rail transit lines. 
It is expected that the remainder of the parking space and the new car parks would be easily filled up after the commencement of the additional 91 rail stations. The success of P\&R facilities shown by the increase of car parking bay users are confirmed in attracting rail passengers with users reported high levels of satisfaction [30]. Therefore, it is necessary to provide more parking space to encourage the usage of rail transportation.

\section{References}

[1] Prasarana Malaysia Berhad, Integrated Rail Transit Map, (2016), Retrieved on July 23, 2016 from http://www.myrapid.com.my/rail/klang-valley-integrated-rail-transit-map

[2] Mass Rapid Transit Corporation, The Klang Valley MRT, (2016), Retrieved on July 23, 2016 from http://www.mymrt.com.my/

[3] Prasarana Malaysia Berhad, LRT 3, (2016), Retrieved on July 23, 2016 from http://www.lrt3.com.my

[4] Land Public Transport Commission, Greater KL/Klang Valley Land Public Transport Master Plan, Malaysia, (2013)

[5] Land Public Transport Commission, Land Public Transport Commission (SPAD) Annual Report 2013, Malaysia, (2013)

[6] Government Transformation Programme, Improving Urban Public Transport, National Key Results Areas, GTP Annual Report 2014, Performance Management and Delivery Unit, (2014)

[7] S.A.A.S Adnan and A.A.K.H Hamsa, Evaluating the parking demand at Park and Ride facility at Putrajaya public transportation terminal, Proceedings of the Eastern Asia Society for Transportation Studies, Taipei, (2013)

[8] N. Abdul Hamid, Utilization patterns of park and ride facilities among Kuala Lumpur commuters, Transportation (Amst)., 36, 295-307 (2009)

[9] U.A. Khalid and A.A.K. Hamsa, Parking utilization pattern of Park and Ride facility at public transportation terminals, Proceedings of the Eastern Asia Society for Transportation Studies, Taipei, (2013)

[10] S. Tamrin, LRT and monorail ridership to reach the two billion mark in May, The Sun Daily, (April 30, 2015)

[11] N.A. Zainal, Putrajaya bus service has far to go, The Star, (March 11, 2015)

[12] N.A. Hamid, J. Mohamad and M.R. Karim, Travel behaviour of the Park and Ride users and the factors influencing the demand for the use of the Park and Ride facility, EASTS International Symposium on Sustainable Transportation incorporating Malaysian Universities Transport Research Forum Conference 2008 (MUTRFC08), Johor Bahru, (2008)

[13] J. Feit, Extended hours and low rates: Parking data in context, Seattle Met, (February $16,2015)$

[14]Department of Statistics, Social Statistical Bulletin Malaysia 2014, Malaysia, (2014)

[15] Department of Statistics, Social Statistical Bulletin Malaysia 2013, Malaysia, (2013)

[16] Department of Statistics, Social Statistical Bulletin Malaysia 2012, Malaysia, (2012)

[17] Department of Statistics, Social Statistical Bulletin Malaysia 2015, Malaysia, (2015)

[18]H. Shang, W. Lin, and H. Huang, Empirical study of parking problem on university campus, J. Transp. Syst. Eng. Inf. Technol., 7, 135-140 (2007)

[19] W. Yan-ling, W. Xin, and Z. Ming-chun, Current situation and analysis of parking problem in Beijing. Procedia Eng., 137, 777-785 (2016)

[20] A.M. Abdullah, M.A.A. Samah and Y.J. Tham, An overview of the air pollution trend in Klang Valley, Malaysia. Open Environ. Sci., 6, 13-19 (2012)

[21] S. Masahina, R. Afroz, J. Duasa and N.A. Mohamed, Framework to estimate the willingness to pay of household for airquality improvement: A case study in Klang 
Valley, Malaysia. Int. J. Sustain. Dev., 4, 11-16 (2012)

[22] M. Brons, M. Givoni and P. Rietveld, Access to railway stations and its potential in increasing rail use, Transp. Res. Part A Policy Pract., 43, 136-149 (2009)

[23] J. Zhao, W. Deng, Y. Song and Y. Zhu. What influences Metro station ridership in China? Insights from Nanjing, Cities, 35, 114-124 (2013)

[24]D. Merriman, How many parking spaces does it take to create one additional transit passenger?, Reg. Sci. Urban Econ., 28, 565-584 (1998)

[25]B.D. Taylor and C.N.Y. Fink, Explaining transit ridership: What has the evidence shown?,Transp. Lett., 5, 15-26 (2013)

[26] A.A.K Hamsa, S.A.A.S Adnan and U.A. Khalid, Analysis of parking usage at the park and ride facility in Klang Valley, Malaysia, WIT Transactions on The Built Environment, 138, 179-193 (2014)

[27] V. Nair, Commuters face daily struggle to find space at LRT stations' parking lot, The Star, (July 29, 2013)

[28]F. Aziz, Parking issue at station, The Star, (October 16, 2009)

[29] N. Zulkifli, Fifteen new LRT stations in Klang Valley begin operations today, New Straits Times Online, (June 30, 2016)

[30] G. Parkhurst, Park and ride: Could it lead to an increase in car traffic?, Transp. Policy, 2, 15-23 (1995) 